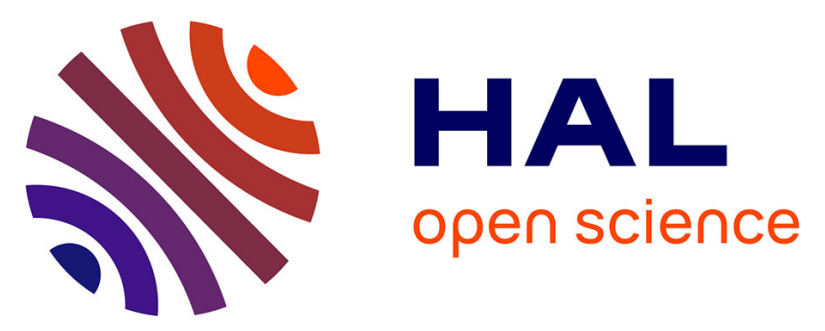

\title{
Rise in RBC aggregability and concomitant decrease in blood pressure 10 days after injection of the long acting erythropoietin analogue methoxy polyethylene glycol-epoetin- $\beta$ (MIRCERA®)
}

Céline Joré, Jean-Frédéric Brun, Emmanuelle Varlet-Marie

\section{To cite this version:}

Céline Joré, Jean-Frédéric Brun, Emmanuelle Varlet-Marie. Rise in RBC aggregability and concomitant decrease in blood pressure 10 days after injection of the long acting erythropoietin analogue methoxy polyethylene glycol-epoetin- $\beta$ (MIRCERA®). Clinical Hemorheology and Microcirculation, 2017, 64 (4), pp.809 - 816. 10.3233/CH-168015 . hal-01818441

\section{HAL Id: hal-01818441 \\ https://hal.umontpellier.fr/hal-01818441}

Submitted on 5 Dec 2019

HAL is a multi-disciplinary open access archive for the deposit and dissemination of scientific research documents, whether they are published or not. The documents may come from teaching and research institutions in France or abroad, or from public or private research centers.
L'archive ouverte pluridisciplinaire HAL, est destinée au dépôt et à la diffusion de documents scientifiques de niveau recherche, publiés ou non, émanant des établissements d'enseignement et de recherche français ou étrangers, des laboratoires publics ou privés. 


\title{
Rise in RBC aggregability
}

\section{and concomitant decrease in blood}

pressure 10 days after injection of the long acting erythropoietin analogue methoxy polyethylene glycol-epoetin- $\beta$ $\left(\right.$ MIRCERA $\left.^{\circledR}\right)$

Céline Joré $^{\mathrm{a}, \mathrm{d}}$, Jean-Frédéric Brun ${ }^{\mathrm{b}, *}$ and Emmanuelle Varlet-Marie ${ }^{\mathrm{a}, \mathrm{c}}$

anstitut des Biomolécules Max Mousseron (IBMM) UMR CNRS 5247, Université de Montpellier, Ecole Nationale Supérieure de Chimie de Montpellier, France

${ }^{\mathrm{b}}$ UMR CNRS 9214- Inserm U1046, Physiopathologie \& Médecine Expérimentale du Cour et des Muscles - PHYMEDEXP, Unité d'Explorations Métaboliques (CERAMM), Université de Montpellier, Département de Physiologie Clinique, Hôpital Lapeyronie CHU Montpellier, France

${ }^{\mathrm{c}}$ Laboratoire de Biophysique \& Bio-Analyses, Faculté de Pharmacie, Université de Montpellier, France ${ }^{\mathrm{d}}$ Laboratoire des Courses Hippiques, Verrières le Buisson, France

\begin{abstract}
Erythropoietin (EPO) is a major regulator of blood viscosity. Its long lasting action analogue methoxy polyethylene glycol-epoetin- $\beta$ (MIRCERA ${ }^{\circledR}$ ) seems to be also employed in modern doping. We took the opportunity of a study aiming at developing a detection of recent MIRCERA ${ }^{\mathrm{TM}}$ injection in the context of doping detection to assess the effects of this EPO analogue on red blood cells (RBC) aggregation. A single dose $200 \mu \mathrm{g}$ of MIRCERA ${ }^{\circledR}$ was injected to 10 male volunteers and blood samplings were drawn over 24 days. After injection a decrease in mean corpuscular volume at day $2(p<0.01)$ and day $10(p<0.02)$, a rise in reticulocyte count $(p<0.001)$ between day 4 and day 17 and a decrease in ferritin a day $5(p<0.05)$ was observed. Hemoglobin decreased at day $4(p<0.005)$. Hematocrit was unchanged. There was a dramatic $(+67 \%)$ increase in RBC aggregation index " $\mathrm{M}$ " (from $9.49 \pm 1.01$ to $17.66 \pm 1.8, p<0.01$ ). A decrease in systolic blood pressure was observed during the period from day 4 to day 17 (at day 10: $-11.90 \pm 2.28 \mathrm{mmHg}, p<0.001$; at day 17: $-15.80 \pm 2.83, p<0.001$ ). There was also a decrease in diastolic blood pressure, mean and pulse pressure. Correlations between this decrease in blood pressure and " $\mathrm{M}$ " did not reach significance but pulse pressure was positively correlated to " $\mathrm{M}$ " $(r=0.743, p<0.05)$.

These data show that the long acting erythropoietin analogue MIRCERA ${ }^{\circledR}$ strongly increases RBC aggregation parallel to a decrease in blood pressure, but a possible causative link between the two events is not clearly evidenced.
\end{abstract}

Keywords: Blood viscosity, hematocrit, exercise, erythrocyte deformability

\section{Introduction}

Erythropoietin, a hormone released by the kidney, is a major regulator of blood viscosity [30]. It experimentally increases hematocrit [19] and has an effect on red cell deformability and aggregation.

${ }^{*}$ Corresponding author: Jean-Frédéric Brun, UMR CNRS 9214- Inserm U1046, Physiopathologie \& Médecine Expérimentale du Cœur et des Muscles - PHYMEDEXP, Unité d'Explorations Métaboliques (CERAMM), Université de Montpellier, Département de Physiologie Clinique, Hôpital Lapeyronie CHU Montpellier, France. Tel.: +33 467338284; Fax: +33 467338986; E-mail: j-brun@chu-montpellier.fr. 
Its long lasting action analogue methoxy polyethylene glycol-epoetin- $\beta$ (MIRCERA ${ }^{\circledR}$; F. HoffmannLa Roche, Basel, Switzerland) is defined as a continuous erythropoietin receptor activator (C.E.R.A.) with a long half-life allowing once-monthly dosing [32]. Its efficacy and safety have been largely studied $[2,11,18,22,25-27]$.

MIRCERA ${ }^{\circledR}$ is likely to be a candidate for modern sports doping. We took the opportunity of a study aiming at developing a detection of recent MIRCERA ${ }^{\circledR}$ injection in the context of doping detection to assess the effects of this EPO analogue on RBC aggregation.

\section{Subjects and methods}

\subsection{Study subjects}

Characteristics of study subjects are presented in Table 1 . This was a group of 10 male volunteers enrolled in the study after informed consent. This protocol was approved by the National Security Agency of Medicines and Health Products (Protocol ID: EudraCT 2014-002090-1).

A single dose $200 \mu \mathrm{g}$ of MIRCERA $^{\circledR}$ was injected in all subjects and blood samplings were drawn over 24 days.

Blood pressure was measured at each visit and we expressed its results as values of systolic and diastolic blood pressure, and also pulse pressure (systolic - diastolic) and mean blood pressure calculated as usual as diastolic $+1 / 3$ of pulse pressure.

\subsection{Hemorheological in vitro measurements}

Blood samples for hemorheological measurements $(7 \mathrm{ml})$ were drawn with potassium EDTA as the anticoagulant in a vacuum tube (Vacutainer). RBC aggregation was assessed with the Myrenne aggregometer [28] which gives two indices of RBC aggregation: "M" (aggregation during stasis after shearing at $600 \mathrm{~s}^{-1}$ ) and "M1" (facilitated aggregation at low shear rate after shearing at $\left.600 \mathrm{~s}^{-1}\right)$.

\subsection{Statistics}

Results are presented as mean \pm the SEM. A value of $p<0.05$ was considered as significant. Comparisons were made with analysis of variance (ANOVA). Correlations were tested by least square fitting for linear, exponential, logarithmic and power relationships.

Table 1

Clinical characteristics of the 10 subjects of the study $($ mean + SEM $)$

\begin{tabular}{lc}
\hline Age $($ years $)$ & $22.00 \pm 1.88$ \\
Weight $(\mathrm{kg})$ & $75.23 \pm 10.91$ \\
Height $(\mathrm{cm})$ & $181.00 \pm 5.35$ \\
Body mass index $\left(\mathrm{kg} / \mathrm{m}^{2}\right)$ & $22.81 \pm 2.74$ \\
Hematocrit $(\%)$ & $45.79 \pm 3.30$ \\
\hline
\end{tabular}




\section{Results}

Figure 1 shows the changes in the 2 aggregation indexes "M" and "M1". Both increase $(p<0.01)$ and we can evidence a dramatic $(+67 \%)$ increase in $\mathrm{RBC}$ aggregation index " $\mathrm{M}$ " on day 10 (from $9.49 \pm 1.01$ to $17.66 \pm 1.8 p<0.01)$.

Table 2 shows the main hemorheologic changes after injection. There was no significant changes in hematocrit. All other changes were significant with ANOVA $(p<0.01)$. Red cell aggregation "M" was higher at day 10 . The rise was not significant with the red cell aggregation "M1" despite marked increases in most individuals due to a decrease in 2 subjects.

On the whole all measurements of blood pressure displayed a decrease over the 24 days of follow-up. Systolic blood pressure was lower on days 7 and $10(p<0.001)$. Diastolic blood pressure was lower on days 7, 10 and 17. Mean blood pressure was lower on days $4(p<0.02), 10(p<0.001), 17(p<0.005)$ and $24(p<0.05)$. Pulse blood pressure was lower on day $10(p<0.05)$. Parallel evolutions of RBC aggregation " $\mathrm{M}$ " and blood pressure are shown on Figs. 2 and 3.

Correlations between this decrease in blood pressure and " $\mathrm{M}$ " did not reach significance but pulse pressure was positively correlated to " $\mathrm{M}$ " $(r=0.743 p<0.05)$, as shown on Fig. 4.

There were also changes that are not shown here and that will be presented in a separate paper. After injection a decrease in mean corpuscular volume at day $2(p<0.01)$ and day $10(p<0.02)$, a rise in

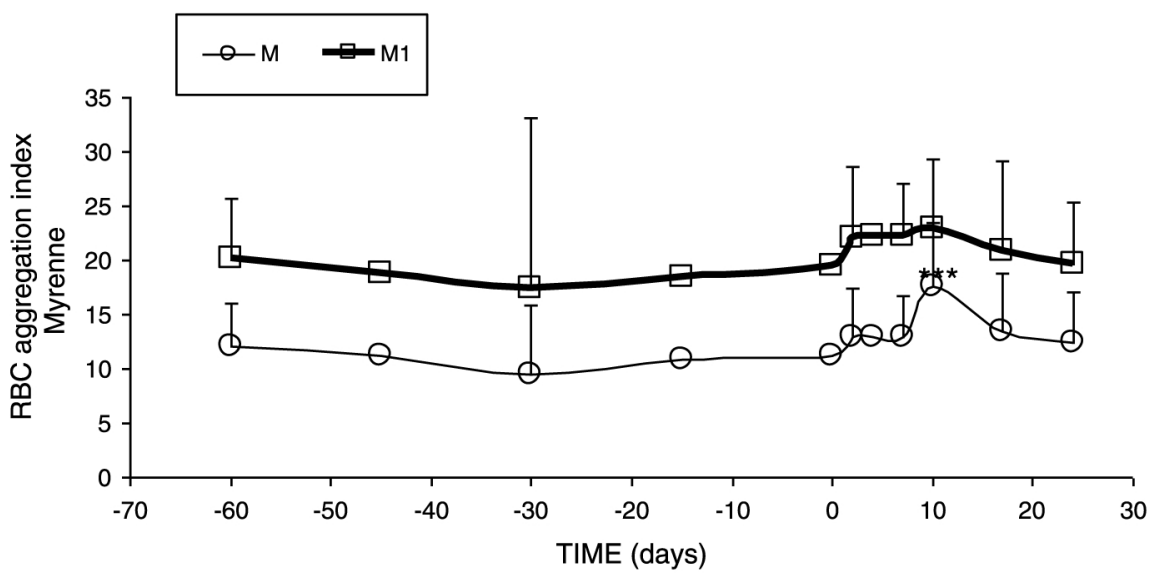

Fig. 1. Evolution of Myrenne RBC aggregation indexes " $M$ " and "M1" before and after a single injection of methoxy polyethylene glycol-epoetin- $\beta$ (MIRCERA ${ }^{\circledR}$ ) performed at day 0 . Overall time effect (ANOVA: $p<0.001$ ). Peak of "M" at day $10^{* * *} p<0.01$.

Table 2

Values of parameters measured during the study (mean + SEM)

\begin{tabular}{|c|c|c|c|c|c|c|c|}
\hline & Day 0 & Day 2 & Day 4 & Day 7 & Day 10 & Day 17 & Day 24 \\
\hline Hematocrit $\%$ & $46.32 \pm 0.78$ & $45.68 \pm 0.92$ & $44.95 \pm 0.81$ & $45.85 \pm 1.06$ & $45.79 \pm 0.67$ & $46.09 \pm 1.15$ & $46.20 \pm 1.24$ \\
\hline RBC aggregation $M$ & $11.29 \pm 1.24$ & $12.88 \pm 1.42$ & - & $12.96 \pm 1.19$ & $17.66 \pm 1.81^{\text {**** }}$ & $13.38 \pm 1.70$ & $12.42 \pm 1.45$ \\
\hline RBC aggregation M1 & $19.49 \pm 1.71$ & $22.11 \pm 2.26$ & - & $22.31 \pm 1.51$ & $22.85 \pm 1.04$ & $20.83 \pm 2.61$ & $19.66 \pm 1.79$ \\
\hline Systolic blood pressure & $129.6 \pm 2.34$ & $125.70 \pm 2.03$ & $121.38 \pm 3.63$ & $121.20 \pm 2.91^{* * * * *}$ & $117.70 \pm 2.14^{* * * * *}$ & $113.80 \pm 2.62$ & $123.10 \pm 3.66$ \\
\hline Diastolic blood pressure & $68.50 \pm 1.15$ & $71.00 \pm 2.98^{* * *}$ & $59.88 \pm 2.30$ & $63.90 \pm 3.09^{* * *}$ & $59.90 \pm 1.76^{*}$ & $61.20 \pm 2.65^{*}$ & $60.00 \pm 2.49$ \\
\hline Mean blood pressure & $88.87 \pm 1.18$ & $89.23 \pm 2.58$ & $80.38 \pm 2.69$ & $83.00 \pm 2.52$ & $79.17 \pm 1.55^{* * * * * * *}$ & $78.73 \pm 2.47^{* * * * * *}$ & $81.03 \pm 2.72$ \\
\hline Pulse blood pressure & $61.10 \pm 2.44$ & $54.70 \pm 1.71$ & $61.60 \pm 1.75$ & $57.30 \pm 2.33$ & $57.80 \pm 2.33^{*}$ & $52.60 \pm 2.02$ & $63.10 \pm 2.32$ \\
\hline
\end{tabular}




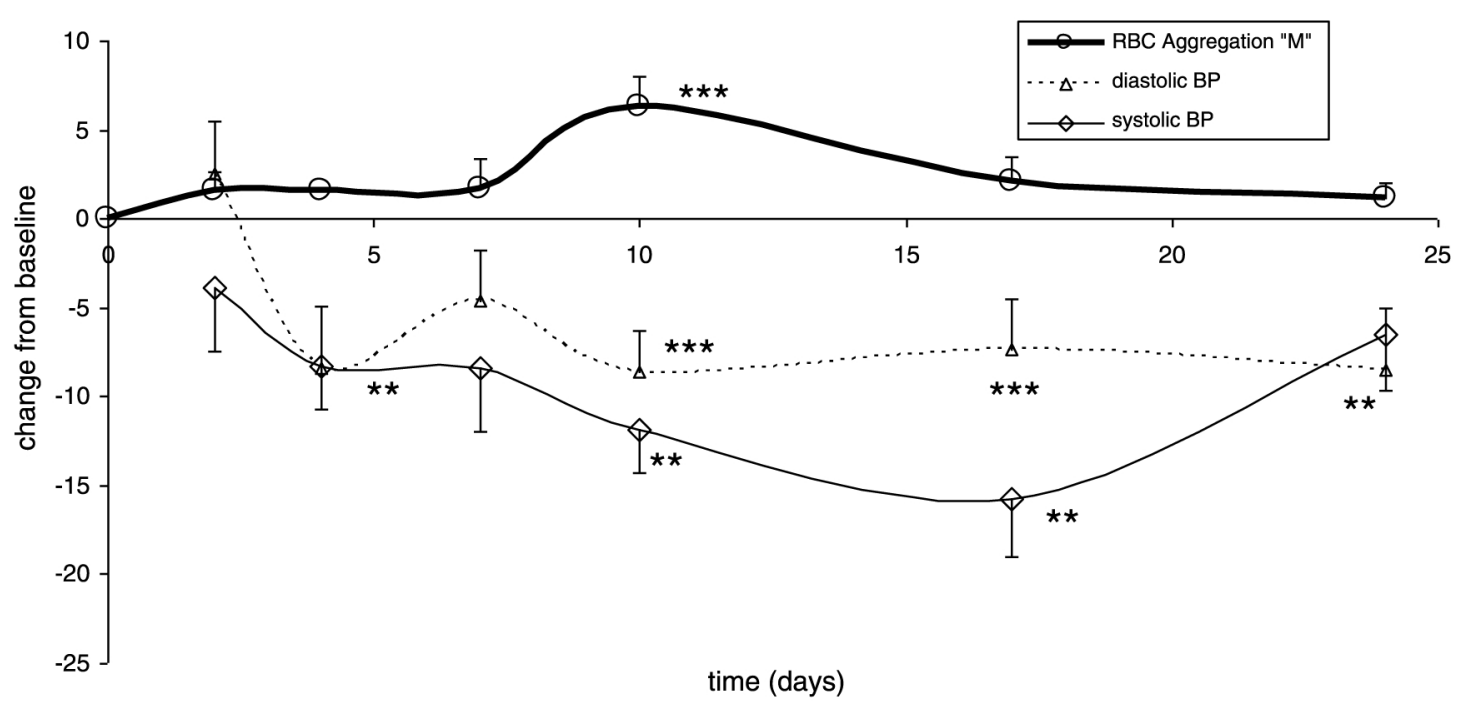

Fig. 2. Parallel evolutions of Myrenne RBC aggregation index " $M$ " and blood pressure (diastolic and systolic) after a single injection of methoxy polyethylene glycol-epoetin- $\beta\left(\right.$ MIRCERA $\left.^{\circledR}\right)$ performed at day $0 .{ }^{*} p<0.05 ;{ }^{* *} p<0.02 ;{ }^{* * *} p<0.01$; **** $p<0.005 ;{ }^{* * * * *} p<0.001$.

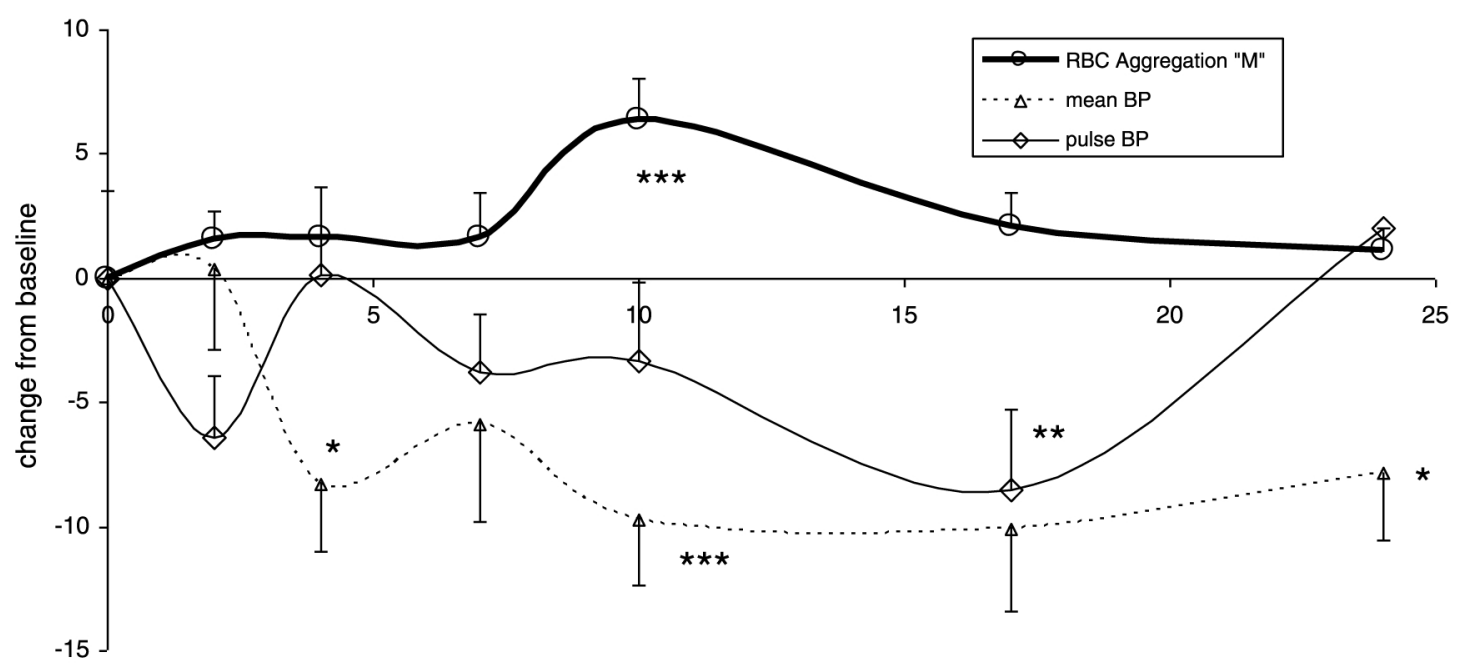

time (days)

Fig. 3. Parallel evolutions of Myrenne RBC aggregation index " $M$ " and blood pressure (pulse pressure and mean pressure) after a single injection of methoxy polyethylene glycol-epoetin- $\beta\left(\right.$ MIRCERA $\left.^{\circledR}\right)$ performed at day $0 .{ }^{*} p<0.05 ;{ }^{* *} p<0.02$; ${ }^{* * *} p<0.01 ;{ }^{* * * *} p<0.005 ;{ }^{* * * * *} p<0.001$.

reticulocyte count $(p<0.001)$ between day 4 and day 17 and a decrease in ferritin a day $5(p<0.05)$. Hemoglobin decreased at day $4(p<0.005)$.

\section{Discussion}

These data show that a single injection of the long acting erythropoietin analogue MIRCERA ${ }^{\circledR}$ increases RBC aggregation parallel to a decrease in blood pressure, while it does not change systemic 


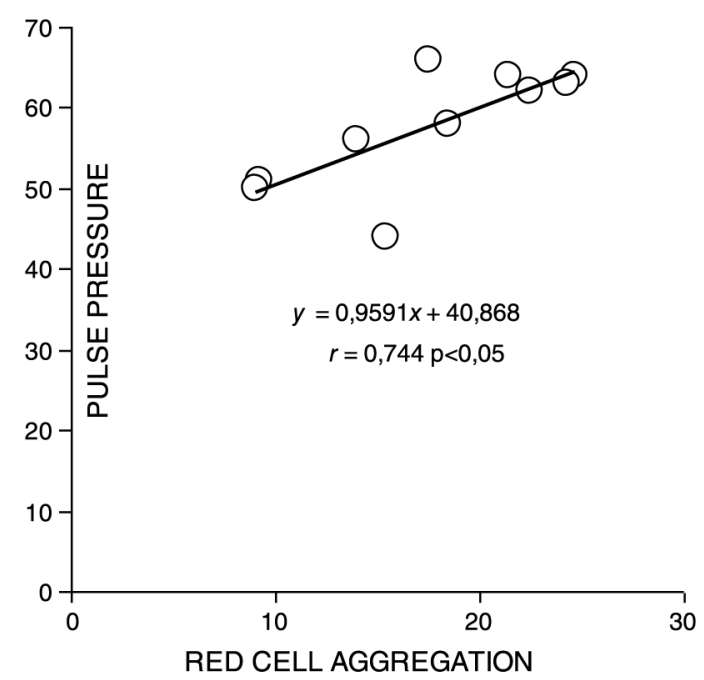

Fig. 4. Linear correlation between red cell aggregation " $M$ " (crude values) and pulse pressure on day 10. A rise in pulse pressure is significantly associated to the rise in red cell aggregation.

hematocrit. Correlations between this decrease in blood pressure and the increase in aggregation did not reach significance. The time course of these various changes is not the same. It can be seen on Figs. 2 and 3 that the decrease in mean, systolic and diastolic blood pressure becomes significant on day 4, before the rise in RBC aggregation, while pulse blood pressure decreases after the peak of RBC aggregation, on day 17. On day 10, during the peak of RBC aggregation, pulse blood pressure is not different from baseline but is positively correlated to RBC aggregation.

There is a large body of literature showing that long-term EPO administration increases blood pressure [33]. Several mechanisms have been described. Erythropoietin potentiates vascular responsiveness to norepinephrine [10] and decreases nitric oxide synthase expression in the endothelial cell [34]. EPO also increases vasoconstrictor tone via endothelin-1 and constrictor prostanoids [3]. There are few studies on long term effects of EPO but in normotensive subjects EPO-induced increases in Hct to approximately $49 \%$ were reported to be associated with a significant increase in resting mean arterial pressure of $+6 \mathrm{mmHg}$ when measured by intra-arterial catheter [17] and with a significantly increased response of blood pressure during exercise [1].

According to Krapf [12] EPO-induced increase in blood pressure is due to its vasoconstrictive effect, caused both by decreased systemic NO production and resistance to NO vasodilation. However this effect is modulated by an ET-1/NO-induced hypotensive effect mediated by inhibition of collecting duct sodium and water reabsorption. This latter effect can in turn be counteracted by EPO which induces sodium retention by a renin-angiotensin II-mediated mechanism at the kidney level [4]. For some authors however, EPO-induced decrease in nitric oxide synthase expression does not explain EPO-induced hypertension [7].

Interestingly, effects of EPO on blood pressure are probably not due to its effects on hematocrit, since a rise in blood pressure is observed after EPO even if hematocrit is kept constant [33] and is not correlated to changes in red blood cell mass and viscosity [12]. A striking demonstration of this dissociation of effects of EPO on blood pressure and hematocrit is given by the fact that a similar increase in hematocrit is associated with increased blood pressure if induced by EPO and decreased blood pressure if induced by transfusion $[5,17]$. 
In contrast with the chronic effect of EPO which is an increase in blood pressure, a single intravenous administration of EPO even at a high-dose (400 and 5,000 U/kg), estimated to yield plasma concentrations comparable with those employed in vitro, does not increase blood pressure and does not modify the blood pressure response to angiotensin II [33].

EPO administration to top endurance athletes is one of the most popular (and apparently successful) doping procedure. In the Tour de France it has been employed on a regular basis by the most famous winning teams [24]. MIRCERA ${ }^{\circledR}$ is a logic candidate for the same use. However, it is clear that the effects of MIRCERA ${ }^{\circledR}$ are not totally similar to those of the native molecule rh-EPO. This may also apply to its hemorheologic effects.

The study of effects of rh-EPO on red cell deformability gave conflictual results. While Taylor reports no change in red cell deformability [31], Schmidt [29] reports a remarkable increase in RBC deformability which is also observed by Delamaire [8]. This fluidification of red cells prevented in part hyperviscosity despite the rise in hematocrit. The recent report that EPO activates nitric oxide synthase in erythrocytes [21] may provide an explanation of this effect. However Linde and coworkers [14] assessed erythrocyte fluidity at Hct $55 \%$ in a 7.4 saline-phosphate buffer at a shear rate of $1 / \mathrm{s}$, in rh-EPO treated patients, and found a more complex picture. There was a decrease in this parameter between weeks 10 and 24 during the rapid production of erythrocytes, followed by a return to normal when the EPO doses were reduced after the target Hct was reached and the production rate diminished. They hypothesized that this EPO-related rigidification of red cells could play an important role in this blood pressure increase.

Concerning red cell aggregation, Delamaire [8] found that it was increased in hemodialyzed patients and EPO treatment resulted in a further increase. By contrast Schmidt [29] found no change in RBC aggregation after EPO.

Clearly, MIRCERA ${ }^{\circledR}$ has a strong, transient effect on RBC aggregation which is markedly increased. In patients receiving erythropoietin analogues (ESAs), there has been reports of cardiovascular and thrombotic events such as myocardial ischaemia and infarction, cerebrovascular haemorrhage and infarction, transient ischaemic attacks, deep venous thrombosis, arterial thrombosis, pulmonary emboli, retinal thrombosis and haemodialysis graft occlusion [23]. Concerning blood pressure, it has been reported to rise in some patients during treatment of anemia with MIRCERA ${ }^{\circledR}$ as with other ESAs.

In the French multicenter, longitudinal, observational study OCEANE adverse effects related to C.E.R.A. were observed in less than $5 \%$ of patients over 1 year of follow-up and led to modification or discontinuation of treatment in 2\% [9]. Data of this series suggest therefore that this EPO analogue is relatively safe. In this respect it is interesting to notice that a single injection of MIRCERA ${ }^{\circledR}$ does not increase hematocrit, while this increase is found with EPO [19].

As reminded above, the link between hemorheologic alterations and blood pressure after EPO is unclear. Moreover, classically, high blood pressure is associated with increased blood viscosity and in particular erythrocyte hyperaggregation $[6,13,15,16,20,35]$ and this study evidences the opposite picture.

\section{Conclusions}

In conclusion, this study shows two effects of a single injection of MIRCERA ${ }^{\circledR}$ : a decrease in blood pressure and a rise in red cell aggregation. The association of these two effects is apparently paradoxical and further studies are needed in order to elucidate this mechanism. 


\section{Acknowledgments}

The authors affirm that they have no disclosure of interest concerning the issue investigated in this paper. This study was presented as poster communication at the 18th Conference of the European Society for Clinical Hemorheology. June 5-8, 2016, Lisbon, Portugal.

\section{References}

[1] B. Berglund and B. Ekblom, Effect of recombinant human erythropoietin treatment on blood pressure and some haematological parameters in healthy men, Journal of Internal Medicine 229 (1991), 125-130.

[2] A. Besarab, M.O. Salifu, N.M. Lunde, V. Bansal, S. Fishbane, F.C. Dougherty and U. Beyer, Efficacy and tolerability of intravenous continuous erythropoietin receptor activator: A 19-week, phase II, multicenter, randomized, open-label, dose-finding study with a 12-month extension phase in patients with chronic renal disease, Clinical Therapeutics 29 (2007), 626-639.

[3] S.M. Bode-Boger, R.H. Boger, M. Kuhn, J. Radermacher and J.C. Frolich, Recombinant human erythropoietin enhances vasoconstrictor tone via endothelin-1 and constrictor prostanoids, Kidney International 50 (1996), 1255-1261.

[4] M.E. Brier, C.M. Bunke, P.V. Lathon and G.R. Aronoff, Erythropoietin-induced antinatriuresis mediated by angiotensin II in perfused kidneys, Journal of American Society of Nephrology 13 (1993), 1583-1590.

[5] F. Celsing, J. Svedenhag, P. Pihlstedt and B. Ekblom, Effects of anaemia and stepwise-induced polycythaemia on maximal aerobic power in individuals with high and low haemoglobin concentrations, Acta Physiologica Scandinavica 129 (1987), 47-54.

[6] C.-M. Chen and D. Schachter, Elevation of plasma immunoglobulin a in the spontaneously hypertensive rat, Hypertension 21 (1993), 731-738.

[7] D. Del Castillo, L. Raij, P.J. Shultz and J.P. Tolins, The pressor effect of recombinant human erythropoietin is not due to decreased activity of the endogenous nitric oxide system, Nephrology Dialysis Transplantation 10 (2000), $505-508$.

[8] M. Delamaire, F. Durand, D. Hamel, V. Joyeux, P. Lepogamp and B. Genetet, Improvement of hemorheologic parameters in hemodialyzed patients treated with human recombinant erythropoietin, Journal Des Maladies Vasculaires 16(3) (1991), 289-294.

[9] L. Frimat, C. Mariat, P. Landais, S. Koné, B. Commenges and G. Choukroun, Anaemia management with C.E.R.A. in routine clinical practice: OCEANE (Cohorte Mircera patients non-dialysés), a national, multicenter, longitudinal, observational prospective study, in patients with chronic kidney disease not on dialysis, BMJ Open 3 (2013), e001888.

[10] M.F. Hand, W.G. Haynes, H.A. Johnstone, J.L. Anderton and D.J. Webb, Erythropoietin enhances vascular responsiveness to norepinephrine in renal failure, Kidney 48 (1995), 806-813.

[11] M. Kessler, A. Martinez-Castelao, K.C. Siamopoulos, G. Villa, B. Spinowitz, F.C. Dougherty and U. Beyer, C.E.R.A. once every 4 weeks in patients with chronic kidney disease not on dialysis: The ARCTOS extension study, Hemodialysis International 14 (2010), 233-239.

[12] R. Krapf and H.N. Hulter, Arterial hypertension induced by erythropoietin and erythropoiesis-stimulating agents (ESA), Clinical Journal of the American Society of Nephrology 4 (2009), 470-480.

[13] R.L. Letcher, S. Chien, T.G. Pickering and J.H. Laragh, Elevated blood viscosity in patients with borderline essential hypertension, Hypertension 5 (1983), 757-762.

[14] T. Linde, B. Sandhagen, B.G. Danielson and B. Wikström, Impaired erythrocyte fluidity during treatment of renal anaemia with erythropoietin, Journal of Internal Medicine 231 (1992), 601-606.

[15] G.J.H. Lip and D.G. Beevers, Abnormalities of rheology and coagulation in hypertension, Journal of Human Hypertension 8(9) (1994), 693-702.

[16] D. Lominadze, I.G. Joshua and D.A. Schuschke, Increased erythrocyte aggregation in spontaneously hypertensive rats, American Journal of Hypertension 11 (1998), 784-789.

[17] C. Lundby, J.J. Thomsen, R. Boushel, M. Koskolou, J. Warberg, J.A. Calbet and P. Robach, Erythropoietin treatment elevates haemoglobin concentration by increasing red cell volume and depressing plasma volume, The Journal of Physiology 578(Pt 1) (2007), 309-314.

[18] I.C. Macdougall, R. Walker, R. Provenzano, et al., on behalf of the ARCTOS study investigators, C.E.R.A. corrects anemia in patients with chronic kidney disease not on dialysis: Results of a randomized clinical trial, Clinical Journal of the American Society of Nephrology 3 (2008), 337-347. 
[19] B. Marson, J.-F. Brun, J.-P. Cristol, M. Audran, J. Mercier and E. Varlet-Marie, Étude de l'effet de la rHuEpo sur le stress oxydant à l'exercice, Science \& Sports 25(2) (2010), 68-73.

[20] H.J. Meiselman, Hemorheologic alterations in hypertension: Chicken or egg? Clinical Hemorheology and Microcirculation 2 (1999), 195-200.

[21] D. Mihov, J. Vogel, M. Gassmann and A. Bogdanova, Erythropoietin activates nitric oxide synthase in murine erythrocytes, American Journal of Physiology - Cellular Physiology 297(2) (2009), C378-C388.

[22] R. Minutolo, P. Zamboli, P. Chiodini, S. Mascia, S. Vitiello, G. Stanzione, V. Bertino, G. Conte and L. De Nicolas, Conversion of darbepoetin to low doses of CERA maintains hemoglobin levels in non-dialysis chronic kidney disease patients, Blood Purification 30 (2010), 186-194.

[23] Notice on MIRCERA at http://researchreview.com.au/MIRCERA_latestPI.pdf

[24] T.L. Pommering, Erythropoietin and other blood-boosting methods, Pediatric Clinics of North America 54 (2007), 691-699.

[25] R. Provenzano, A. Besarab, I.C. Macdougall, D.H. Ellison, A.P. Maxwell, W. Sulowicz, M. Klinger, B. Rutkowski, R. Correa-Rotter and F.C. Dougherty, The continuous erythropoietin receptor activator (C.E.R.A.) corrects anemia at extended administration intervals in patients with chronic kidney disease not on dialysis: Results of a phase II study, Clinical Nephrology 67 (2007), 306-317.

[26] S.D. Roger, F. Locatelli, R.P. Woitas, M. Laville, S.W. Tobe, R. Provenzano, T.A. Golper, P. Ruangkanchanasetr, H.Y. Lee, K.-D. Wu, M. Nowicki, A. Ladanyi, A. Martinez-Castelao, U. Beyer and F.C. Dougherty, C.E.R.A., once every 4 weeks corrects anaemia and maintains haemoglobin in patients with chronic kidney disease not on dialysis, Nephrology Dialysis Transplantation 26 (2011), 3980-3986.

[27] A. Sanchez-Fructuoso, L. Guirado, J.C. Ruiz, V. Torregrosa, E. Gonzalez, M.L. Suarez and R. Gallego, On behalf of the Anemia Trans Study Group, Anemia control in kidney transplant patients treated with methoxy polyethylene glycol-epoetin beta (Mircera): The Anemiatrans Group, Transplantation Proceedings 42 (2010), 2931-2934.

[28] H. Schmid-Schönbein, E. Volger and H.J. Klose, Microrheology and light transmission of blood III: The velocity of red cell aggregate formation, Pflugers Archiv European Journal of Physiology 254 (1975), 299-317.

[29] R. Schmidt, D. Lerche, E. Dörp, R. Winkler and H. Klinkmann, Changes in rheology and red blood cell function under recombinant human erythropoietin therapy, Polskie Archiwum Medycyny Wewnetrznej 85(6) (1991), 384-390.

[30] A. Singh, K.U. Eckardt, A. Zimmermann, K.H. Götz, M. Hamann, P.J. Ratcliffe, A. Kurtz and W.H. Reinhart, Increased plasma viscosity as a reason for inappropriate erythropoietin formation, Journal of Clinical Investigation 91 (1993), 251.

[31] J.E. Taylor, J.J.F. Belch, M. McLaren, I.S. Henderson and W.K. Stewart, Effect of erythropoietin therapy and withdrawal on blood coagulation and fibrinolysis in hemodialysis patients, Kidney International 44 (1993), 182-190.

[32] J.M. Topf, CERA: Third-generation erythropoiesis-stimulating agent, Expert Opinion on Pharmacotherapy 9 (2008), 839-849.

[33] N. D. Vaziri, X.J. Zhou, J. Smith, F. Oveisi, K. Baldwin and R.E. Purdy, In vivo and in vitro pressor effects of erythropoietin in rats, American Journal of Physiology - Renal Physiology 269(6) (1995), F838-F845.

[34] X.Q. Wang, X.Q. and N.D. Vaziri, Erythropoietin depresses nitric oxide synthase expression by human endothelial cells, Hypertension 33 (1999), 894-899.

[35] F. Zannad and J.-F. Stoltz, Blood rheology in arterial hypertension, Journal of Hypertension 10(suppl 5) (1992), S69-S78. 